\title{
Stage I Ureter Cancer AJCC v8
}

National Cancer Institute

\section{Source}

National Cancer Institute. Stage I Ureter Cancer A/CC v8. NCI Thesaurus. Code C140366.

Stage I includes: T1, N0, M0. T1: Tumor invades subepithelial connective tissue. N0: No regional lymph node metastasis. M0: No distant metastasis. (AJCC 8th ed.) 